\title{
The Importance of an Invasive Aphid Species in Vectoring a Persistently Transmitted Potato Virus: Aphis glycines Is a Vector of Potato leafroll virus
}

\author{
J. A. Davis, Department of Entomology, Louisiana State University Agricultural Center, Baton Rouge 70803; and \\ E. B. Radcliffe, University of Minnesota, Department of Entomology, St. Paul 55108
}

\begin{abstract}
Davis, J. A., and Radcliffe, E. B. 2008. The importance of an invasive aphid species in vectoring a persistently transmitted potato virus: Aphis glycines is a vector of Potato leafroll virus. Plant Dis. $92: 1515-1523$

Experiments were undertaken to determine soybean aphid (i) landing rates in potato fields, (ii) population dynamics on potato, (iii) feeding behavior compared with green peach aphid on potato using the electrical penetration graph technique (EPG), (iv) acquisition, retention, and transmission of Potato leafroll virus (PLRV), and (v) if soybean aphid-infested crop borders could increase PLRV spread in seed potato. Soybean aphid (Aphis glycines) landed on potato but failed to establish colonies. EPG showed no significant differences between the aphid species in preprobe, xylem phase, sieve element salivation, and phloem sap ingestion durations on potato. Soybean aphid acquired PLRV $78 \%$ of the time, and 75 and $70 \%$ of individual aphids retained infectivity after 72 and $144 \mathrm{~h}$, respectively. Soybean aphid transmitted PLRV to susceptible potato with 6 to $9 \%$ efficiency. Prior to the invasion of this exotic pest, soybean borders were commonly used in Minnesota and North Dakota to protect seed potato against spread of Potato virus $Y$. In 2002 and 2004, PLRV incidence was not different in potatoes with soybean borders whether treated with insecticide or not. In 2005, with extreme soybean aphid pressure, potatoes with untreated (no insecticide) borders had significantly greater PLRV spread. This is the first report of soybean aphid transmitting PLRV.
\end{abstract}

Additional keywords: virus vector epidemiology

Soybean aphid (Aphis glycines Matsumura), an exotic pest of soybean (Glycine $\max (\mathrm{L}$.$) Merrill), is considered one of the$ most significant risks to soybean production in North America (43). Found in over 21 states and 3 Canadian provinces (56), soybean aphid can directly damage soybean by reducing pod set, seed quality, and yield $(36,39)$. In addition, soybean aphid is known to transmit both nonpersistently $(12,15,57)$ and persistently $(14,28,52)$ transmitted viruses. Soybean aphid has been implicated in increased virus incidence in soybean (35) and snap bean (37). Soybean aphid is a proficient virus vector because of its high fecundity, short generation time (34), and propensity to form alatae (winged morphs) (26).

Cultural manipulations that interfere with the phototactic responses of vector aphids can disrupt host plant selection and restrict virus spread (3). Aphids are attracted to contrasts between plant canopy and soil (49), and aphid landing rates can be inhibited by reducing the plant/soil contrast (1) or by using highly reflective

Corresponding author: Jeffrey A. Davis

E-mail: JeffDavis@agcenter.lsu.edu

Accepted for publication 9 July 2008.

doi:10.1094/PDIS-92-11-1515

(c) 2008 The American Phytopathological Society surfaces (31). The use of mulches, such as aluminum foil (23), white plastic (61), and oat straw (46), and the use of whitewash (33) reduce spread of insect-vectored pathogens in various crops.

Crop borders (barrier crops) take advantage of plant canopy/soil contrasts, reducing Potato virus $Y$ (PVY) transmission to potato (Solanum tuberosum L.) (18). Dispersing alatae carrying PVY feed first on the crop border and lose infectivity before moving into potato (18). Use of soybean crop borders to protect seed potatoes from PVY spread has been widely adopted by Minnesota and North Dakota potato growers due to its ease of maintenance, compatibility with potato herbicides, and lack of insect pests. In addition, soybean is not a host for PVY. The recent emergence of soybean aphid as a major pest throughout the Midwest (56) and our discovery that this insect is a capable vector of PVY (15) raises questions about the advisability of using soybean as a crop border.

Potato leafroll virus (PLRV; family Luteoviridae, genus Polerovirus) is a circulative, persistently transmitted virus which can also reduce potato yields and cause net necrosis, a darkening of the vascular bundles, leading to reduced quality and marketability (30). PLRV is a phloem restricted virus found abundantly in companion cells (54), and aphids must feed on phloem tissue to acquire and transmit the virus. PLRV is primarily transmitted by potato-colonizing aphid species: cotton aphid (Aphis gossypii Glover), buckthorn aphid (Aphis nasturtii Kaltenbach), foxglove aphid (Aulacorthum solani (Kaltenbach)), potato aphid (Macrosiphum euphorbiae (Thomas)), green peach aphid (Myzus persicae (Sulzer)), and bulb and potato aphid (Rhopalosiphoninus latysiphon (Davidson)), but PLRV has been known to be transmitted by noncolonizing species: pea aphid (Acyrthosiphon pisum (Harris)), black bean aphid (Aphis fabae Scopoli), crescent-marked lily aphid (Aulacorthum circumflexum (Buckton)), shallot aphid (Myzus ascalonicus Doncaster), violet aphid (Myzus ornatus Laing), damson-hop aphid (Phorodon humuli (Schrank)), and Rhopalosiphoninus staphyleae tulipaellus Theobald $(29,47)$. Movement of PLRV into potato fields is primarily by alatae (10), but within-field spread of PLRV is often by apterae (wingless aphids) (21).

Soybean aphid is not known to colonize potato but does colonize another solanaceous host, horsenettle (Solanum carolinense L.) (13). Soybean aphid is also congeneric with two known PLRV vectors, buckthorn aphid and cotton aphid. Recent surveys of certified potato seed lots conducted by this laboratory to determine the type and extent of potato viruses indicate that incidence of PLRV may be increasing (16). Because soybean aphid can increase to high numbers on soybean, and soybean is being used as a crop border, we were prompted to evaluate the potential of soybean aphid to transmit PLRV. For soybean aphid to spread PLRV, it must be able to move to potato fields and ingest phloem sap and sieve element salivate for several minutes to acquire and transmit PLRV. Objectives of this study were to determine soybean aphid (i) landing rates in potato fields, (ii) population dynamics of soybean aphid on potato, (iii) feeding behavior of soybean aphid on potato using the electrical penetration graph (EPG) technique, (iv) acquisition, retention, and transmission of PLRV, and (v) if soybean aphid-infested soybean crop borders contribute to PLRV spread.

\section{MATERIALS AND METHODS}

Aphid colonies. Aphid colonies maintained in the laboratory were used in all transmission experiments. The soybean aphid colony was founded from a single apterous adult collected from soybean at 
the University of Minnesota Outreach, Research and Education Park (UMORE Park), Rosemount, MN, in 2001 and reared on soybean (cv. M96-133151) planted in 10-cm-diameter plastic pots containing sterile potting mix (Sun Gro Horticulture, Elma, MB) and $5 \mathrm{~g}$ of Osmocote (14-1414), a slow-release fertilizer (The Scotts Company, Marysville, OH) in GC15 EGC Plant Growth Chambers (Environmental Growth Chambers, Chagrin Falls, $\mathrm{OH}$ ) held at $25 \pm 2{ }^{\circ} \mathrm{C}, 75 \pm 3 \% \mathrm{RH}$, and a photoperiod of 16:8 (L:D). The green peach aphid colony used in these experiments was founded from a single apterous adult field-collected from potato at UMORE Park in 2002 and maintained on Chinese cabbage (Brassica rapa L. subsp. pekinensis (Lour.) Hanelt) (Gurney's Seed and Nursery Co., Yankton, SD) planted as above. Soybean and Chinese cabbage are not hosts of PLRV (27).

Virus source. The PLRV isolate (PLRVMNR06) used in transmission experiments was collected from potato (cv. Russet Burbank) grown at UMORE Park in 2006. PLRV-MNR06 was isolated from its original source by green peach aphid single probe transmission to virus-free potato and was maintained by successive aphid transmissions to Russet Burbank planted and grown as described in aphid colonies. This isolate elicits typical PLRV symptoms: pale yellow leaves tinged with purple or red and often rolled (4).

Test plants. Soybean (cv. M96-133151) and potato (cvs. Red La Soda, Russet Burbank, and Russet Norkotah) were planted and maintained as described in aphid colonies. When soybean had reached growth stage V4 (20), and 6 weeks after potato emergence, plants were used for experiments.

Virus detection. To identify PLRV infection in potato test plants, leaflets were sampled and leaf sap was expressed using a pasta roller as described in Flanders et al. (22). Extracted leaf sap was then stored at $-20^{\circ} \mathrm{C}$ in $1.5-\mathrm{ml}$ microcentrifuge tubes (Sarstedt Inc., Newton, NC). PLRV detection was performed by double-antibody sandwich enzyme-linked immunosorbent assay (DAS-ELISA) using polyclonal kits according to manufacturer's protocols (Agdia, Elkhart, IN). Absorbance was measured at $405 \mathrm{~nm}$ with a Bio-Rad 450 Plate Reader (Bio-Rad Laboratories, Inc., Hercules, CA). Plants were considered positive if optical density readings were greater than the mean of five negative controls (noninfected plants) plus three times their standard deviation (51). Reverse transcriptase-polymerase chain reaction (RTPCR) was conducted on all plants and aphids. Viral RNA was extracted using a Qiagen (Valencia, CA) RNeasy Plant Mini Kit, and RT-PCR was performed with a Qiagen OneStep RT-PCR Kit, following manufacturer's specifications. Primers designed for the detection of PLRV came from Singh et al. (48). All RT-PCR products were visualized on $2 \% 1 \times$ TBE agarose gels stained with ethidium bromide and then photographed. Infection rates were calculated as number of infected test plants divided by total number of test plants and expressed as a percentage.

Aphid landing rates in potato. To determine how often soybean aphid landed in potato fields, aphid landing rates were mined from the Aphid Alert trapping network data set. More information on Aphid Alert can be found in Radcliffe et al. (42). In short, Aphid Alert was an aphid trapping network designed to provide near real-time information to potato seed producers on which potato virus vector species were present and their abundance to enable pest management decisions. Soybean aphid was first captured in the traps of the Aphid Alert network in 2001.

In 2001 and 2002, aphid landing rates in seed potato fields were estimated by trapping aphids at 27 locations in five states (Minnesota, Nebraska, North Dakota, South Dakota, and Wisconsin). In 2003, traps were operated at eight Minnesota and North Dakota locations only. Aphid trapping at each sampling site was done using two methods: (i) by employing one lowvolume $\left(2.4 \mathrm{~m}^{3} \mathrm{~min}^{-1}\right)$ 2.3-m-tall suction trap designed to monitor Russian wheat aphid (Diuraphis noxia (Mordvilko)) in the western United States (2), and (ii) by two green ceramic tiles (Dal-Tile, Dallas, TX) placed individually in 1.4-liter plastic containers (Servin Saver, Rubbermaid, Wooster, $\mathrm{OH})$ partially filled with a 50:50 mixture of propylene glycol and water (19). Traps were emptied weekly and aphids were counted and identified to species.

For purposes of the present study, aphid trap counts were placed into three categories: potato colonizing species, noncolonizing species, and Soybean aphid. This was done to distinguish among aphid species known to vector PLRV (colonizing species), aphids that do not vector PLRV but are very important in PVY transmission due to their high population rates (noncolonizing species), and Soybean aphid. The Colonizer category included the five aphid species that typically colonize potato in North America, which are green peach aphid, potato aphid, cotton aphid, buckthorn aphid, and foxglove aphid (41). The category Noncolonizer included four aphid species that do not colonize potato and have low PVY vector efficiencies, but can be important in potato virus epidemiology due to their sheer numbers: bird cherry-oat aphid (Rhopalosiphum padi (L.)), corn leaf aphid (Rhopalosiphum maidis (Fitch)), English grain aphid (Sitobion avenae (F.)), and greenbug (Schizaphis graminum (Rondani)) (44). Mean aphid numbers per week per category were then calculated.

Population dynamics of soybean aphid and green peach aphid on potato.
To determine the population dynamics of soybean aphid and green peach aphid on potato, single apterous, aphid adults were transferred to each potato test plant using a \#2037 nylon brush (Loew-Cornell, Inc., Englewood Cliffs, NJ), confined throughout the experiment in a 1.5 -cm-diameter clip cage on the abaxial surface of a leaf on the upper third of each potato test plant, and allowed to larviposit for $12 \mathrm{~h}$. The adult and all but one first-instar were then removed. All single first-instars were the cohort for that experiment $(n=15)$. Test plants were placed in black $28 \times 56 \mathrm{~cm}$ plastic plant trays in GC15 EGC Plant Growth Chambers held at $20 \pm 0.2^{\circ} \mathrm{C}, 50 \pm$ $5 \% \mathrm{RH}$, and a photoperiod of 16:8 (L:D). Three potato cultivars (Russet Burbank, Russet Norkotah, and Red La Soda) were used, and tests were replicated (independent experiment) three times per cultivar per aphid species. Life tables were then constructed for each potato cultivar and each aphid species following the methods of Birch (6). Cohorts were checked daily. Age $(x)$, age-specific survival $\left(l_{x}\right)$, days to reproductive adult (DTRA), and number of progeny per female per day $\left(m_{x}\right)$ were recorded, and age-specific fecundity $\left(l_{x} m_{x}\right)$ was calculated.

Electrical penetration graph (EPG) studies. To compare soybean aphid probing behavior on potato to that of green peach aphid, EPG experiments were conducted in a Faraday cage using a Giga 4 DC EPG amplifier with 1 Giga Ohm input resistance and an $\mathrm{AD}$ conversion rate of $100 \mathrm{~Hz}$ (Wageningen Agricultural University, Wageningen, The Netherlands). A DAS-800 Digital Acquisition Card (Keithley Instruments, Inc., Cleveland, $\mathrm{OH}$ ) converted analog signals into digital, which were visualized and recorded using WinDaq/Lite software (DATAQ Instruments, Inc., Akron, $\mathrm{OH})$. Feeding behavior waveforms identifying specific aphid probing activities were distinguished using characteristics listed in Tjallingii and Hogen Esch (53). Apterous adults were removed from either soybean (soybean aphid) or Chinese cabbage (green peach aphid) and immediately used in feeding behavior studies. A 2$\mathrm{cm}$ length of $25-\mu \mathrm{m}$ gold wire (GoodFellow Metal Ltd., Cambridge, UK) was attached to the aphid dorsum with silver conductive paint (Pelco Colloidal Silver no. 16034, Ted Pella, Inc., Redding, CA). Three potato (Russet Burbank) test plants were placed randomly within the Faraday cage. Next, one aphid per test plant was then placed on the abaxial side of a leaf and feeding behavior was recorded for 4 $\mathrm{h}$, giving sufficient time for the aphid to phloem feed. This was repeated 10 times, 30 aphids per species, $120 \mathrm{~h}$ of aphid feeding on potato per aphid species. Preprobe, xylem phase (G), E1 (sieve element salivation), and E2 (phloem sap ingestion) durations were recorded per 4$\mathrm{h}$ feeding bout. 
Soybean aphid PLRV acquisition tests. To ascertain if soybean aphid could acquire PLRV, acquisition tests were conducted. Adult apterae in groups of 5,10, or singly were given a $2-\mathrm{h}$ preacquisition fast after which they were confined in a 1.5$\mathrm{cm}$-diameter clip cage on the abaxial surface of a PLRV-infected potato test plant and allowed an acquisition access period (AAP) of $24 \mathrm{~h}$. Aphids were removed and placed into $1.5-\mathrm{ml}$ microcentrifuge tubes and stored at $-20^{\circ} \mathrm{C}$. Acquisition tests were repeated five times and each replicate consisted of 12 single aphids, 6 groups of 5 aphids, and 5 groups of 10 aphids. Viral RNA was extracted and PLRV detected by RT-PCR as stated in Virus detection.

Soybean aphid PLRV retention tests. Tests were conducted to ascertain if soybean aphid could retain PLRV over time. Adult apterae in groups of 5, 10, or singly were given a 2 -h preacquisition fast, after which they were confined in a $1.5-\mathrm{cm}-$ diameter clip cage on the abaxial surface of a PLRV-infected potato test plant and allowed an AAP of $24 \mathrm{~h}$. Aphids were then placed in 1.5-cm-diameter clip cages on the abaxial surface of a leaf on the upper third of a stage V6 soybean. Aphids were held in clip cages for 72 and $144 \mathrm{~h}$, giving sufficient time for any PLRV particles to be purged from their digestive systems. Aphids were removed and placed into 1.5$\mathrm{ml}$ microcentrifuge tubes and stored at $-20^{\circ} \mathrm{C}$. Retention tests were repeated five times for each retention period, and each replicate consisted of 12 single aphids, six groups of 5 aphids, and five groups of 10 aphids. Viral RNA was extracted and PLRV detected by RT-PCR as stated in Virus detection.

PLRV transmission tests. Adult apterae were used in all transmission tests. Transmission efficiencies were measured using soybean aphids in groups of three or individually. To provide comparisons of vector efficiency, single aphid experiments included a known PLRV vector, green peach aphid, tested as individuals. Aphids were given a 2-h preacquisition fast, after which they were confined in a $1.5-\mathrm{cm}$ diameter clip cage on the abaxial surface of a PLRV-infected potato test plant and allowed an AAP of $24 \mathrm{~h}$. Aphids were then placed in 1.5 -cm-diameter clip cages on the abaxial surface of a leaf on the upper third of a V6 soybean plant and held in clip cages for $144 \mathrm{~h}$. Aphids were then placed into 1.5-cm-diameter clip cages on the abaxial surface of a leaf on the upper third of each PLRV-free potato test plant and given an inoculation access period (IAP) of $24 \mathrm{~h}$. Transmission tests were repeated five times, and each replicate consisted of four single green peach aphids (PLRV infected and uninfected acquisition plant), nine or four single soybean aphids (PLRV infected and uninfected acquisition plant, respectively), and seven or two groups of three aphids (PLRV infected and unin-

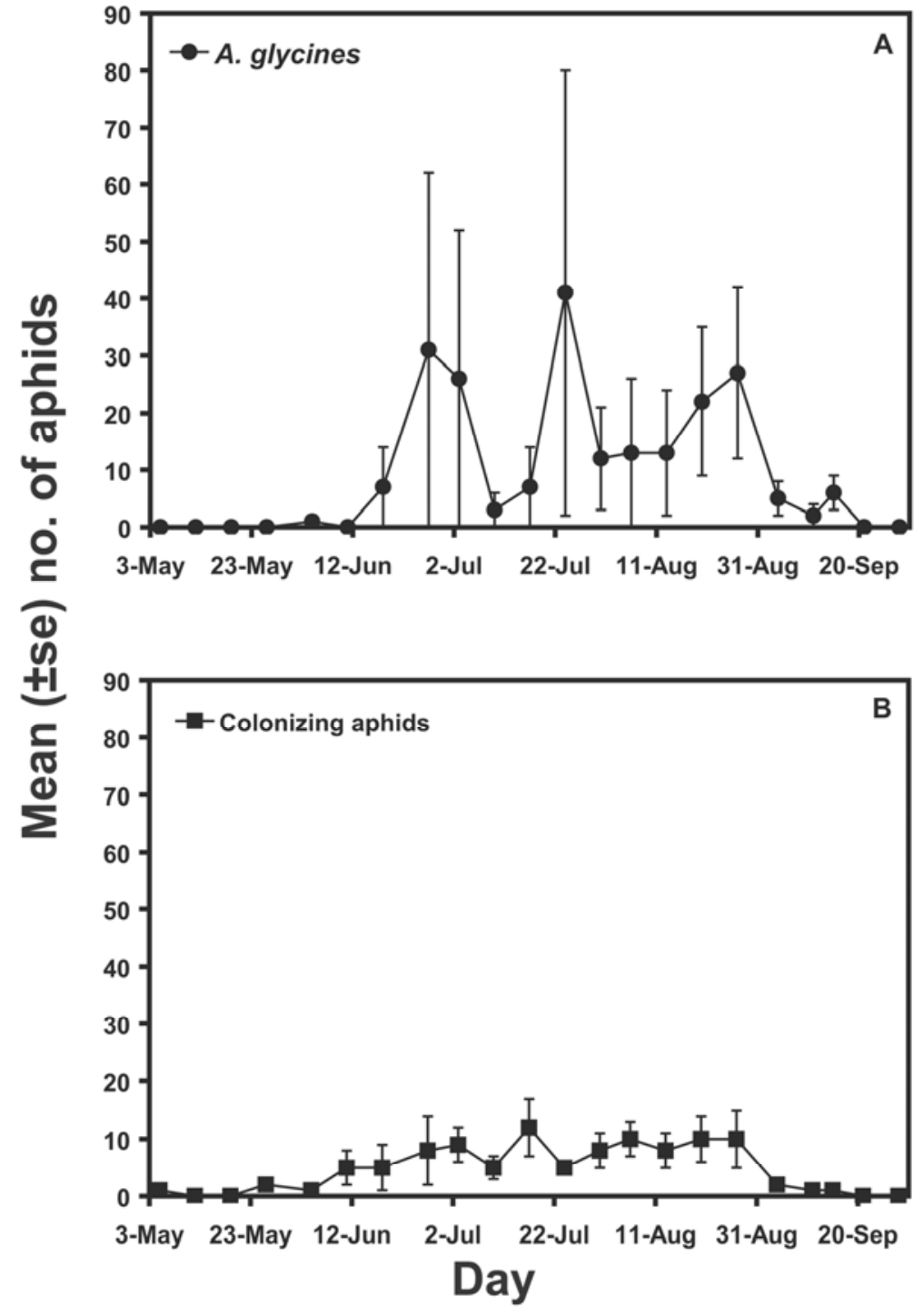

Fig. 1. Mean number of aphids per trap per week \pm SE caught in potato for the years 2001 to 2003. A, Aphis glycines (soybean aphid), and $\mathbf{B}$, potato colonizing aphid species (green peach aphid and potato aphid).

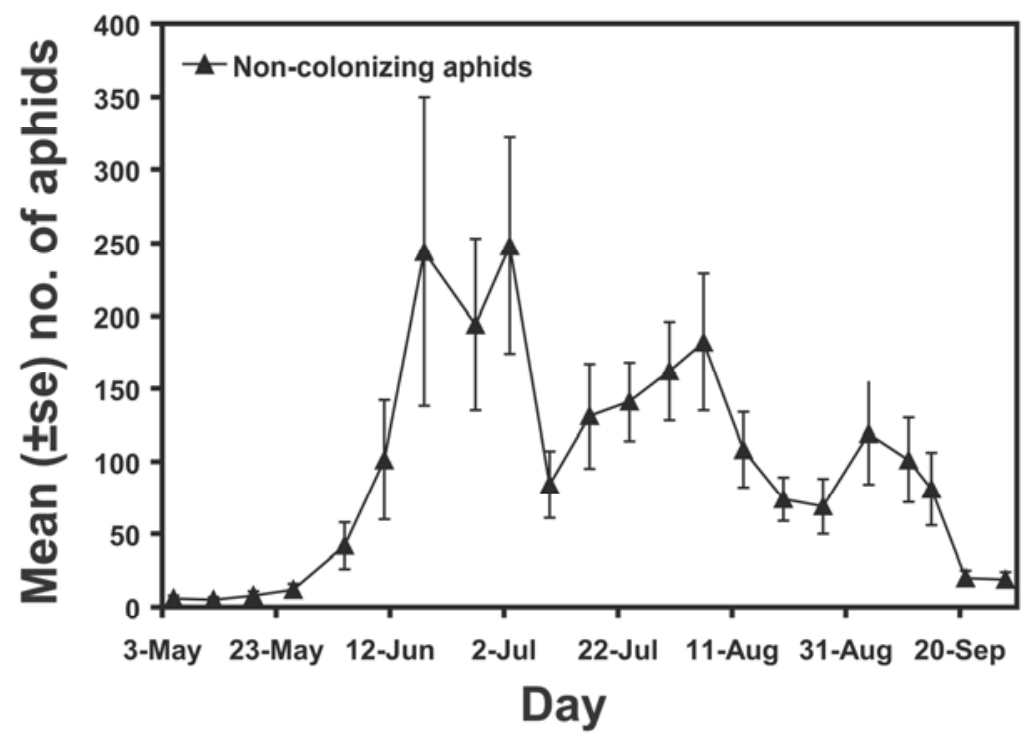

Fig. 2. Mean number of noncolonizing aphid species per trap per week \pm SE caught in potato for the years 2001 to 2003. Noncolonizing aphid numbers depicted in this figure include these four aphid species: bird cherry-oat aphid, corn leaf aphid, English grain aphid, and greenbug. 
fected acquisition plant, respectively). Aphids were manually removed and test plants were soil treated with imidacloprid (Marathon 1\% G, $0.02 \mathrm{~g}$ a.i./pot) and placed in a greenhouse for 2 weeks for symptom development. In addition, control tests were conducted using virus-free acquisition plants following the above proce-
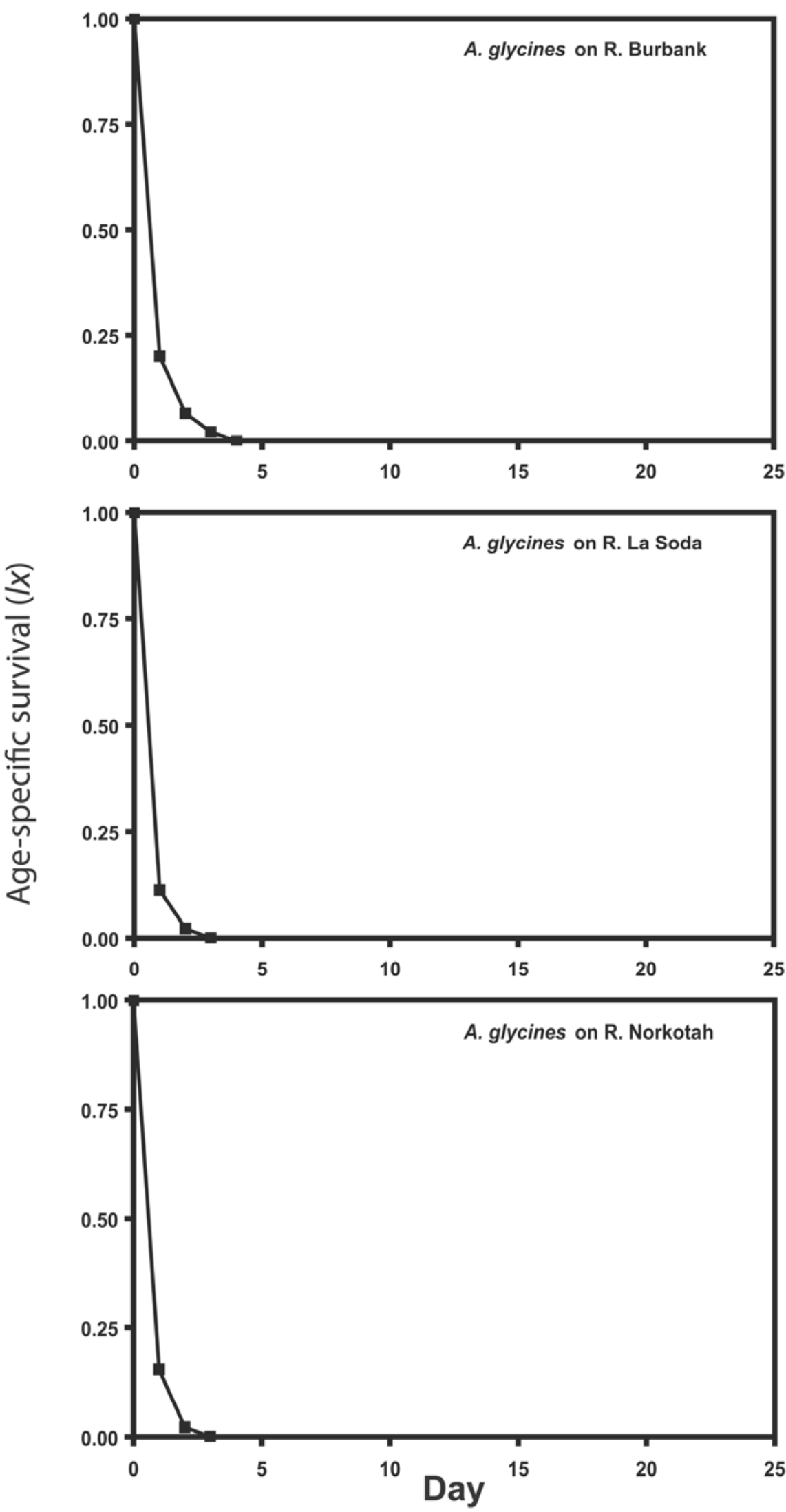

Fig. 3. Age-specific survivorships $\left(l_{x}\right)$ for soybean aphid reared on potato cultivars Russet Burbank, Red La Soda, and Russet Norkotah.

dures. This assured that PLRV infection was not from an outside source.

Serial PLRV transmission tests. To ensure soybean aphid-transmitted PLRV was still infectious and not a selected subpopulation of PLRV that might not be transmissible by green peach aphid, serial PLRV transmission was tested. First, individual $(n=16)$ apterous soybean aphids were given a 2 -h preacquisition fast, after which they were confined in a $1.5-\mathrm{cm}-$ diameter clip cage on the abaxial surface of a PLRV-infected potato test plant and allowed an AAP of $24 \mathrm{~h}$. In addition, as a control, 10 apterous soybean aphids never exposed to PLRV were placed into $1.5-\mathrm{cm}$ diameter clip cages on the abaxial surface of a leaf on the upper third of each PLRVfree potato test plant and given an IAP of $24 \mathrm{~h}$. Aphids were then placed in $1.5-\mathrm{cm}$ diameter clip cages on the abaxial surface of a leaf on the upper third of a V6 soybean plant and held in clip cages for $144 \mathrm{~h}$. Aphids were then placed into $1.5-\mathrm{cm}$ diameter clip cages on the abaxial surface of a leaf on the upper third of each PLRVfree potato test plant and given an IAP of $24 \mathrm{~h}$. Aphids were manually removed and test plants were placed in a greenhouse for 2 weeks for symptom development.

After symptoms developed, individual $(n=10)$ apterous green peach aphids were given a 2-h preacquisition fast, after which they were confined in $1.5-\mathrm{cm}$-diameter clip cages on the abaxial surface of soybean aphid PLRV-infected plants and allowed an AAP of $24 \mathrm{~h}$. Aphids were then placed into 1.5 -cm-diameter clip cages on the abaxial surface of a leaf on the upper third of each PLRV-free potato test plant and given an IAP of $24 \mathrm{~h}$. Aphids were manually removed and test plants were soil treated with imidacloprid (Marathon 1\% G, $0.02 \mathrm{~g}$ a.i./pot) and placed in a greenhouse for 2 weeks for symptom development.

Crop borders. Field trials to determine if soybean aphid-infested soybean crop borders could contribute to PLRV spread were conducted at UMORE in 2002, 2004, and 2005. To measure background levels of PLRV, 300 tubers were randomly sampled from each certified potato seed lot prior to planting, grown in the greenhouse, and tested by ELISA 6 weeks after emergence. Early generation certified seed potatoes were planted on 14 May 2004 (Red La Soda) and on 16 May 2002 and 2005 (Russet Burbank) at 2.2 MT/ha, 47,000 plants/ha. Plots consisted of four rows 10.1 $\mathrm{m}$ long of seed potatoes $(0.9 \mathrm{~m}$ between rows and $0.3 \mathrm{~m}$ within-row spacing), with a 3.7-m-wide soybean crop border on either side; eight plots total. Soybean was planted 19 May 2002 (Pioneer variety 91B91) and 2004 and 6 June 2005 (Asgrow variety AG2106) at 470,000 seed/ha. Two rows of virus-infected potatoes ( $30 \%$ PLRV infected) were planted $6.1 \mathrm{~m}$ on either side of each plot to serve as inoculum sources. At planting, all potatoes 
were treated in-furrow with imidacloprid (Admire 2F) at $0.3 \mathrm{~kg}$ a.i./ha to control Colorado potato beetle (Leptinotarsa decemlineata (Say)). Imidacloprid does not affect aphid dispersal or probing behavior but significantly reduces flight propensity and flight distance (8). Soil-applied imidacloprid has inconsistent effects on PLRV spread, significantly reducing PLRV infection in only 1 out of 3 years (9). All potatoes received weekly application of chlorothalonil (Bravo $\mathrm{Zn}$ ) at a rate of 0.84 $\mathrm{kg}$ a.i./ha for late blight (Phytophthora infestans (Mont.) de Bary) control starting 7 July. To determine if borders colonized by aphids would influence PLRV spread, four plots each year received bimonthly applications of lambda-cyhalothrin (Warrior) at $0.03 \mathrm{~kg}$ a.i./ha starting $23 \mathrm{July}$ 2004 and 13 July 2002 and 2005; four plots each year received no insecticide. Soybean aphid populations were measured weekly starting 5 July by randomly selecting 10 soybean plants per border and counting total number of aphids per plant. From these data, cumulative insect days (CID) (45) were calculated for each treatment. Diquat dibromide (Reglone), a desiccant, was applied at 0.86 liters a.i./ha on 23 August to kill vines. Two weeks after vine kill, 100 tubers were randomly sampled per plot (800 tubers total), placed into mesh bags, labeled, and shipped to the Hawaii Agriculture Research Center (HARC) field station, Kunia, Oahu in November 2004 or Twin Bridge Farms, Waialua, Oahu in 2005 where they were planted. In 2002, tubers were placed into mesh bags, labeled, and kept in cold storage for 3 months. Tubers were then planted and grown as described in Test plants. Leaf samples were collected from each plant and were indexed for PLRV infection by ELISA and RT-PCR.

Data analysis. Data were tested for normality by the Kolmogorov-Smirnov test in PROC CAPABILITY and tested for homogeneity by the Levene test for homogeneity of variances in PROC GLM (general linear model) using SAS software for Windows v.9.1 (SAS Institute Inc., Cary, NC). Feeding behavior data were normally distributed and analysis of variance (ANOVA) was performed using PROC GLM to test for differences in probing behaviors. The RyanEinot-Gabriel-Welsch multiple range test (REGWQ) was used to separate means, $P=$ 0.05 . Transmission efficiency was estimated as number of infected test plants divided by total number of test plants, expressed as a percentage. For groups of 3, 5, or 10 aphids, the maximum likelihood estimator (MLE) was also used (55). MLE was calculated as $1-(1-x / m)^{1 / k}$, where $x$ was the number of test plants positive for PVY, $m$ was the total number of test plants, and $k$ was the number of aphids used per test plant. Confidence intervals for MLE were calculated using the Microsoft Excel add-in PooledInfRate Version 3.0 (5). Significant differences in
PLRV infection rates between soybean border insecticide-treated and untreated categories were tested using Pearson's chisquare test in the statistical program $\mathrm{R}$ (The $\mathrm{R}$ Project for Statistical Computing: http://www.r-project.org). Yates' continuity correction was used when cell values in contingency tables were less than 5 (50).

\section{RESULTS}

Aphid landing rates in potato. Mean number of aphids per trap caught in potato
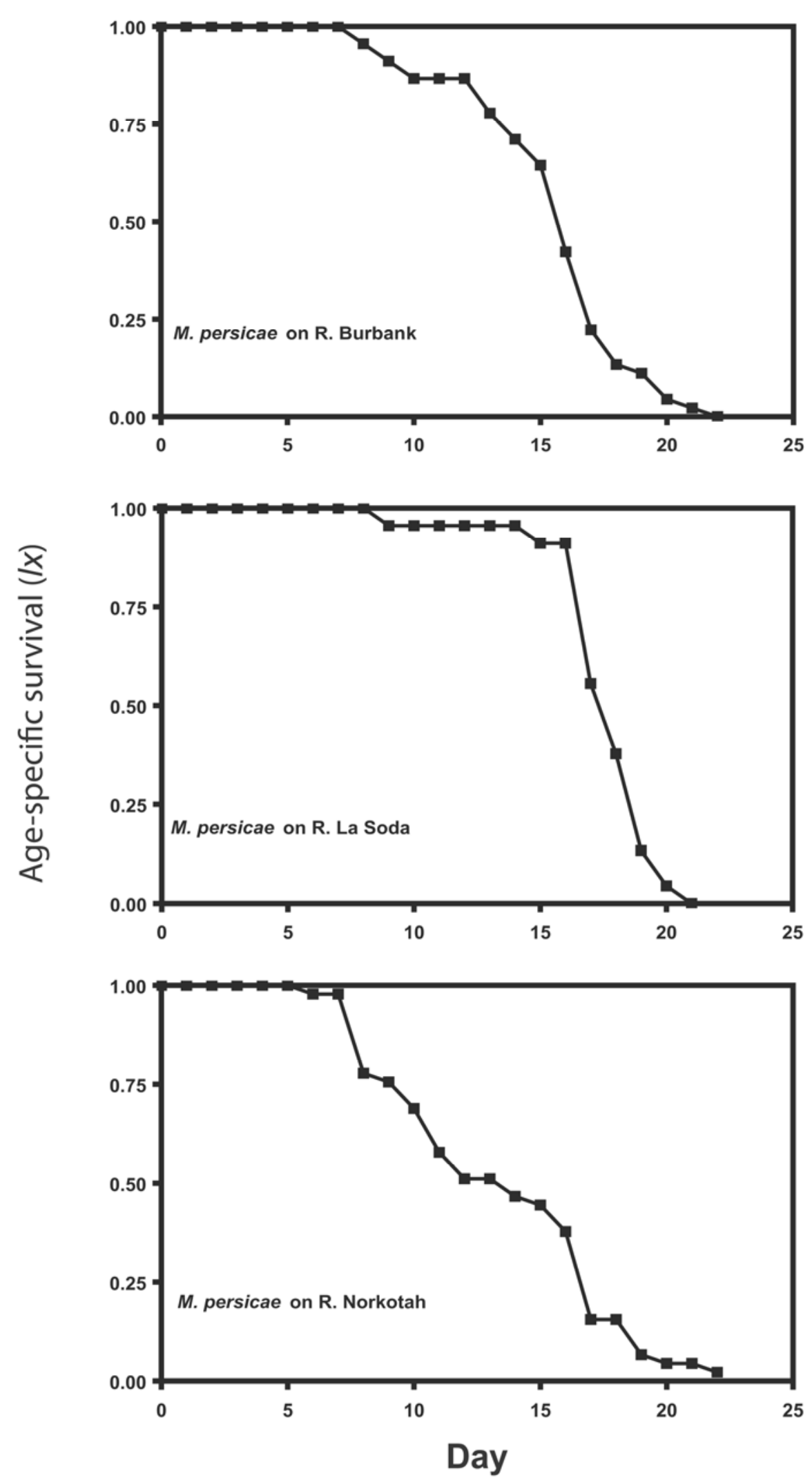

Fig. 4. Age-specific survivorships $\left(l_{x}\right)$ for green peach aphid reared on potato cultivars Russet Burbank, Red La Soda, and Russet Norkotah. 
for the years 2001 to 2003 are shown in Figures 1 and 2. Soybean aphid settled in seed potato fields and there were three distinct periods of soybean aphid alate activity: mid-June, mid-July, and midAugust (Fig. 1A). In contrast, there were no catches of cotton aphid, buckthorn aphid, or foxglove aphid. Thus, for the Colonizer category, trap captures consisted solely of green peach aphid and potato aphid. Mean number of colonizing aphids per trap per week reached 10 by 10 July, but never exceeded 30 any week (Fig. 1B). Mean noncolonizing aphid numbers exceeded all other categories in mid-June and continued to do so through September (Fig. 2).

Population dynamics of soybean aphid and green peach aphid on potato. Age-specific survival $\left(l_{x}\right)$ for soybean aphid and green peach aphid on three different potato cultivars (Russet Burbank, Red La Soda, and Russet Norkotah) is shown in Figures 3 and 4. Soybean aphid had high nymph mortality, typical of a Type II survivorship curve, on potato with 75 to $89 \%$ of nymphs (cultivar specific) perishing within $24 \mathrm{~h}$. No soybean aphid reached reproductive adulthood on potato. Green peach aphid flourished on potato with no nymph mortality. Green peach aphid DTRA (mean \pm SE) were $7.8 \pm 0.3$ on Russet Burbank, $8.2 \pm 0.2$ on Red La Soda, and $8.0 \pm 0.3$ on Russet Norkotah. Mean number of green peach aphid progeny per female per day $\left(m_{x}\right)$ was $0.9 \pm 0.1$ for Russet Burbank, $2.2 \pm 0.3$ for Red La Soda, and $0.8 \pm 0.1$ for Russet Norkotah.

EPG studies. There were no significant differences among aphid species for: mean preprobe duration $(F=1.23$; df $=1 ; P=$ $0.3488)$, mean xylem phase $(\mathrm{G})$ duration $(F=0.37 ; \mathrm{df}=1 ; P=0.5511)$, mean sieve element salivation (E1) $(F=0.10$; df $=1$; $P=0.7557)$ or mean phloem sap ingestion (E2) durations $(F=0.95$; $\mathrm{df}=1 ; P=$ 0.3360) (Table 1). In $4 \mathrm{~h}$, soybean aphid fed similarly to green peach aphid. On

Table 1. Probing behavior of soybean aphid and green peach aphid on potato cultivar Russet Burbank $^{\mathrm{x}}$

\begin{tabular}{lcc}
\hline & \multicolumn{2}{c}{ Time engaged $(\mathbf{s})^{\mathbf{y}}$} \\
\cline { 2 - 3 } Parameter $^{\mathbf{z}}$ & $\begin{array}{c}\text { Soybean } \\
\text { aphid }\end{array}$ & $\begin{array}{c}\text { Green peach } \\
\text { aphid }\end{array}$ \\
\hline Preprobe & $642 \pm 115 \mathrm{a}$ & $418 \pm 125 \mathrm{a}$ \\
& $(n=189)$ & $(n=383)$ \\
$\mathrm{G}$ & $2,032 \pm 551 \mathrm{a}$ & $1,540 \pm 252 \mathrm{a}$ \\
& $(n=17)$ & $(n=16)$ \\
$\mathrm{E} 1$ & $8.6 \pm 1.7 \mathrm{a}$ & $10.3 \pm 3.2 \mathrm{a}$ \\
& $(n=24)$ & $(n=48)$ \\
E2 & $247 \pm 159 \mathrm{a}$ & $413 \pm 134 \mathrm{a}$ \\
& $(n=24)$ & $(n=48)$ \\
\hline
\end{tabular}

${ }^{\mathrm{x}}$ Within a 4-h period.

${ }^{y}$ Means $( \pm$ SE) followed by same letter within columns are not significantly different $(P>$ 0.05 ) by the Ryan-Einot-Gabriel-Welsch multiple range test (REGWQ).

${ }^{\mathrm{z}}$ Xylem phase $(\mathrm{G})$, sieve element salivation (E1), and phloem sap ingestion (E2). potato, soybean aphid reached vascular tissue, sieve element salivated (necessary for PLRV transmission), and phloem sap ingested (necessary for PLRV acquisition).

Soybean aphid PLRV acquisition and retention tests. Soybean aphid acquired PLRV at $78 \%$ (single aphid), $13 \%$ (in groups of 5), and 20\% (in groups of 10) efficiency (Table 2). Soybean aphid retained PLRV for 72 and $144 \mathrm{~h}$. Single apterous soybean adults acquired PLRV at higher rates than aphids in groups, leading to higher percentages of single adults retaining PLRV. There was no significant loss of PLRV retention over time.

PLRV transmission tests. Aphids did not perish during transmission studies. Soybean aphid transmitted PLRV at 9\% efficiency (single aphid) and 6\% in groups of three (Table 3). This indicates that PLRV virus particles passed from the hemocoel into accessory salivary glands. Green peach aphid was a more efficient vector of PLRV, transmitting at $95 \%$ efficiency. There was no transmission of PLRV from virus-free acquisition sources.

Serial PLRV transmission tests indicated soybean aphid-transmitted PLRV was still infectious (Table 4). Soybean aphid trans- mitted PLRV at 13\% efficiency (single aphid). Then, the soybean aphid PLRVinfected plants were used as PLRV source plants for green peach aphid PLRV transmission. Green peach aphid transmitted PLRV at $80 \%$ efficiency. There was no transmission of PLRV when the acquisition source was virus free.

Crop borders. Soybean aphid CID in treated soybean borders reached 636, 3 , and 160 in 2002, 2004, and 2005, respectively (Fig. 5). Soybean aphid CID in untreated soybean borders reached $15,139,708$, and 28,170 in 2002, 2004 and 2005, respectively. Certified potato seed lot PLRV infection levels prior to planting test plots were 5\% in 2002, $1 \%$ in 2004, and $0 \%$ in 2005. PLRV levels were not significantly different in potato seed lots bordered by insecticide-treated and untreated soybean borders in 2002 and $2004\left(\chi^{2}=1.08,0.03 ; \mathrm{df}=1,1 ; P=\right.$ $0.2977,0.8545$ ) (Table 5). However, in 2005, PLRV levels were significantly different in potato seed lots bordered by treated and untreated soybean borders, and this was coincident with high soybean aphid CID in untreated plots $\left(\chi^{2}=\right.$ $8.39 ; \mathrm{df}=1 ; P=0.0038)$.

Table 2. Soybean aphid Potato leafroll virus (PLRV) acquisition and retention

\begin{tabular}{lllccc}
\hline Test & Single/group $^{\mathbf{x}}$ & $\boldsymbol{n}^{\mathbf{y}}$ & Retention period & \% PLRV + & CI $^{\mathbf{z}}$ \\
\hline Acquisition & Single & 60 & $0 \mathrm{~h}$ & 78 & 67 to 87 \\
& Group of 5 & 30 & $0 \mathrm{~h}$ & 13 & 8 to 20 \\
& Group of 10 & 25 & $0 \mathrm{~h}$ & 28 & 16 to 45 \\
Retention & Single & 60 & $72 \mathrm{~h}$ & 75 & 63 to 85 \\
& Group of 5 & 30 & $72 \mathrm{~h}$ & 15 & 9 to 23 \\
& Group of 10 & 25 & $72 \mathrm{~h}$ & 12 & 7 to 18 \\
& Single & 60 & $144 \mathrm{~h}$ & 70 & 58 to 81 \\
& Group of 5 & 30 & $144 \mathrm{~h}$ & 17 & 10 to 25 \\
& Group of 10 & 25 & $144 \mathrm{~h}$ & 5 & 3 to 9 \\
\hline
\end{tabular}

$\mathrm{x}$ Tested in groups of 5,10 , or as individuals.

y Number of groups.

z $95 \%$ Confidence intervals of PLRV infection rates.

Table 3. Soybean aphid and green peach aphid Potato leafroll virus (PLRV) transmission tests

\begin{tabular}{llllcc}
\hline Aphid species & Single/group & $\boldsymbol{n}^{\mathbf{y}}$ & Source & \% PLRV + & CI $^{\mathbf{z}}$ \\
\hline Green peach aphid & Single & 20 & Infected & 95 & 78 to 100 \\
& Single & 20 & Not infected & 0 & $\ldots$ \\
Soybean aphid & Single & 43 & Infected & 9 & 9 to 21 \\
& Single & 20 & Not infected & 0 & $\ldots$ \\
& Group of 3 & 32 & Infected & 6 & 3 to 12 \\
& Group of 3 & 10 & Not infected & 0 & $\ldots$ \\
\hline
\end{tabular}

${ }^{x}$ Tested in groups of three or as individuals.

${ }^{y}$ Number of groups.

z $95 \%$ Confidence intervals of PLRV infection rates.

Table 4. Serial Potato leafroll virus (PLRV) transmission tests

\begin{tabular}{lllcc}
\hline Aphid species & $\boldsymbol{n}^{\mathbf{x}}$ & Source & \% PLRV + & CI $^{\mathbf{y}}$ \\
\hline Aphis glycines & 16 & Infected & 13 & 2 to 35 \\
& 10 & Not infected & 0 & $\ldots$ \\
Myzus persicae & 10 & SBA PLRV infected & 80 & 49 to 100 \\
& 10 & SBA PLRV not infected & 0 & $\ldots$ \\
\hline
\end{tabular}

${ }^{\mathrm{x}}$ Number of individual aphids.

y 95\% Confidence intervals of PLRV infection rates.

${ }^{z}$ Soybean aphid. 


\section{DISCUSSION}

Soybean aphid has had a profound direct impact on North American soybean production. For instance, in 2003, 2.1 of 4.2 million ha of MN soybeans were treated for soybean aphid (32). Soybean aphids can have direct effects on yield, with losses ranging from 6 to $32 \%$ (36). However, the

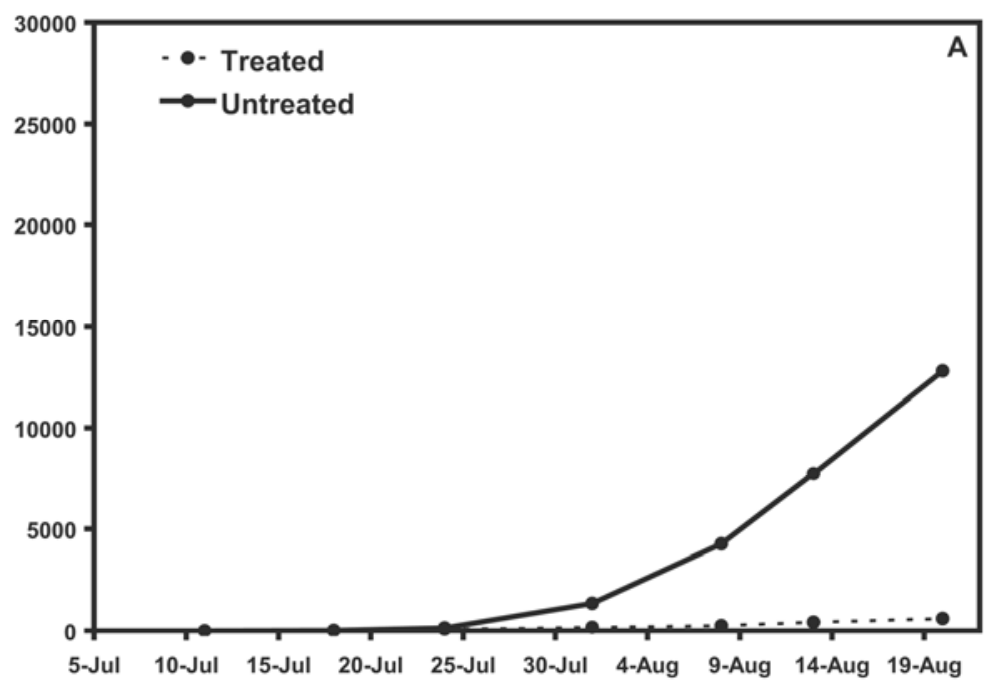

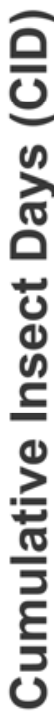
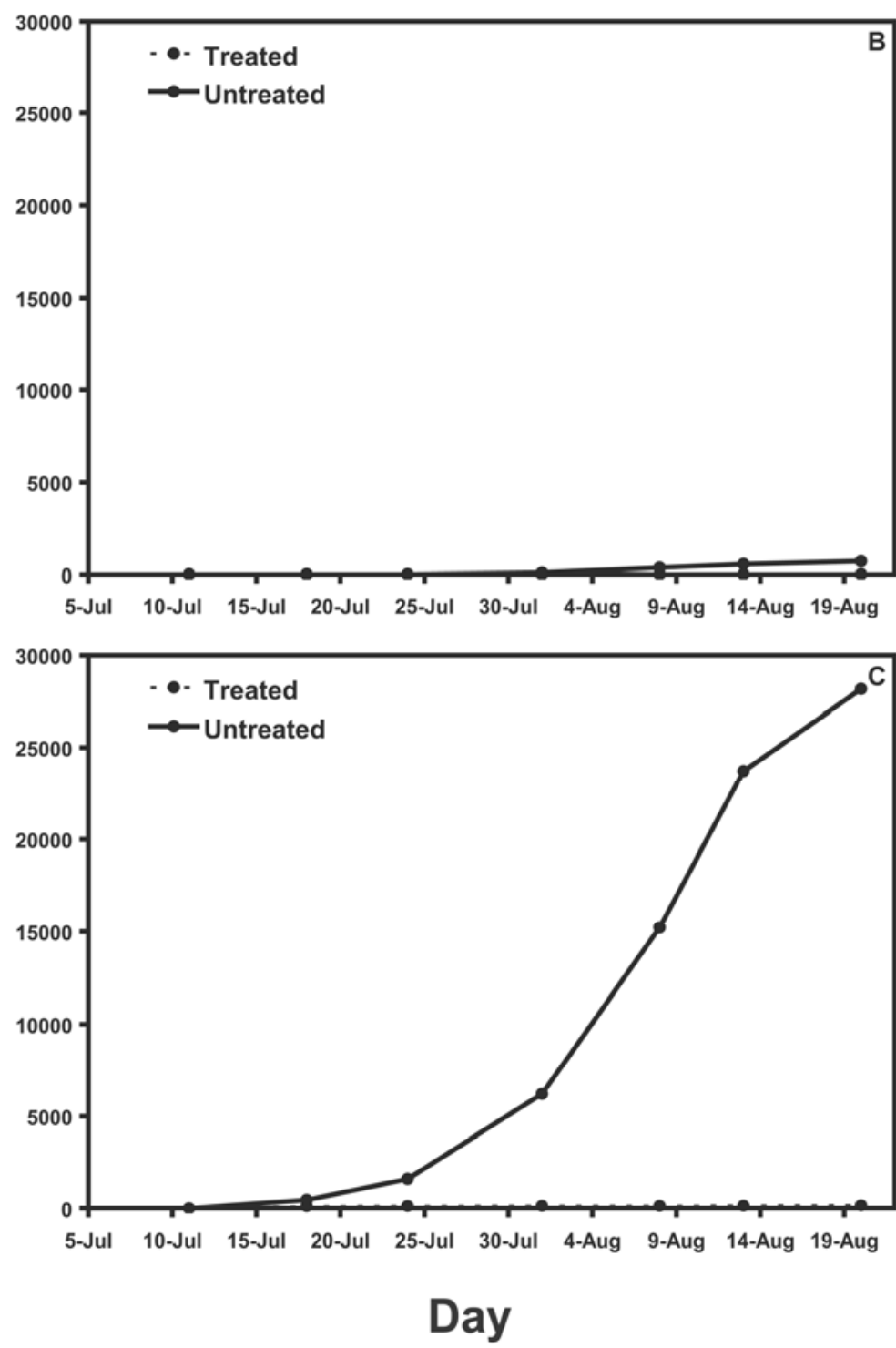

Fig. 5. Soybean aphid cumulative insect days (CID) on treated and untreated soybean crop borders surrounding seed potato test plots. A, 2002; B, 2004; C, 2005.

indirect effects of this aphid as a virus vector are just starting to become known. In the United States, soybean aphid has been implicated in the increase in nonpersistent virus incidence in soybean (35), snap bean (37), and potato (16). Although soybean aphid has the potential to vector persistently transmitted viruses (58), it has not been implicated in their field transmission in the United States. In this report, we show apparently for the first time that soybean aphid can vector a persistently transmitted potato virus, PLRV, even though the aphid does not colonize potato. In addition, we provide evidence that soybean aphidinfested soybean borders can result in increased PLRV spread in seed potato.

How great an impact soybean aphid has on the seed potato industry will depend on many epidemiological factors. We have provided evidence that soybean aphid does settle in seed potato fields early and throughout the season when dispersing from its overwintering host, buckthorn (Rhamnus cathartica L.), and from soybean. Potatoes are most susceptible to virus infection during vegetative growth (59); therefore, PLRV transmission could be increased by soybean aphid since it tends to arrive early in the season. We have shown that soybean aphid did not have feeding behaviors significantly different from the most efficient vector of PLRV, green peach aphid. Soybean aphid does not colonize potato, but given our findings on feeding behavior and since soybean aphid can colonize a closely related species (horsenettle), there is some possibility that this aphid may adapt to colonize potato. Plants that become infected early can be PLRV acquisition sources later in the season. Soybean aphid has low PLRV vector efficiency, 6 to $9 \%$. What soybean aphid lacks in vector efficiency, it makes up for in its high fecundity, short generation time, and propensity to form alatae.

Soybean aphid vector efficiency was different between individuals and groups of aphids. Vector efficiency may have been affected by aphid alarm pheromone, and this seems to be the case in our acquisition and transmission studies using groups of aphids. Alarm pheromone is produced when aphids are disturbed, either by a

Table 5. Comparison of Potato leafroll virus (PLRV) infection levels in potato seed tuber lots grown in plots with treated and untreated soybean crop borders

\begin{tabular}{llc}
\hline Year & Soybean $_{\text {border }}$ & \% PLRV \\
\hline 2002 & Treated & 55 \\
& Untreated & 59 \\
2004 & Treated & 3 \\
& Untreated & 2 \\
2005 & Treated & 23 \\
& Untreated & 32 \\
\hline
\end{tabular}

${ }^{\mathrm{z}}$ Treated soybean borders received bimonthly applications of lambda-cyhalothrin (Warrior) at $0.03 \mathrm{~kg}$ a.i./ha. 
predator or by mechanical stimulation (40). Aphids respond to alarm pheromone by dispersing, and once exposed to alarm pheromone, are more sensitive to stimuli (38). Soybean aphid is known to excrete an exudate from their cornicles which contains an alarm pheromone (11). Soybean aphids coming into contact with this exudate became restless and dispersed (11). Alarm pheromone can increase preprobe duration (62) and inhibit virus acquisition and transmission of nonpersistent (24) and persistent (17) viruses. Care should be taken in future greenhouse virus vector studies when using small cages and groups of aphids. Even in an agricultural setting, soybean aphid acquisition and transmission of PLRV could be affected by alarm pheromone. Soybean aphid does not colonize potato and is not found in groups on potato; thus, alarm pheromone should not cause disturbance on potato. However, on soybean crop borders with high soybean aphid populations alongside potato, disturbance would be likely and could increase PLRV spread. Crowded plant conditions will increase the release of alarm pheromone, making aphids disperse, increasing the chance soybean aphid will acquire and transmit PLRV.

Movement of potato viruses into a field is by winged aphids (7). The proportion of alates found on soybean is small (1\%) through early July (26). However, by midJuly, the proportion reaches $10 \%$. The economic threshold (ET) for soybean aphid on soybean is $273 \pm 38$ aphids per plant (43). To estimate the number of alate soybean aphids emerging from a 100-ha field, assume a typical plant stand of $\sim 65,000$ plants per ha. If soybean growers maintain soybean aphid populations below the ET rate and we set the number of aphids per plant at 100 , we can project that a 100-ha field in mid-July would harbor 65 million alates. Our research has shown that $70 \%$ of soybean aphids can acquire and retain PLRV for $144 \mathrm{~h}$. If even $6 \%$ of alate soybean aphids were able to acquire and transmit PLRV, a 100-ha soybean field could provide 2.7 million potential PLRV vectors capable of moving into an adjacent potato field. Thus, there is the potential for widespread PLRV transmission to occur if inoculum is available even though soybean aphid has low vector efficiency compared to green peach aphid. With typical PLRV tolerances for seed potato certification being in the 0 to $1 \%$ range (60), even a small amount of PLRV transmission can be economically devastating.

Within-field PLRV movement is primarily by apterae (wingless aphids) (21), and apterae can walk as far as $8 \mathrm{~m}$ per day in field (25). Thus, there is the potential for soybean crop borders to impact withinfield spread of PLRV. We have confirmed this, showing that at high CID $(28,000)$, significant current season spread of PLRV did occur. To reduce the spread of PLRV, growers using soybean crop borders will need to monitor for soybean aphid. When Ragsdale et al. (43) attempted to keep soybean aphid CID at 0 , populations still reached $1,567 \pm 446$. If soybean aphid reached 240 aphids per plant on 22 July and stayed at this level through 2 September, CID would reach approximately 12,000. Our data suggest CID levels below 12,000 might not cause significant PLRV spread. Growers must still be cautious, however, in allowing large soybean aphid populations to persist in close proximity to their potato seed fields.

\section{ACKNOWLEDGMENTS}

We thank C. A. Clark for constructive comments on this manuscript.

\section{LITERATURE CITED}

1. A'Brook, J. 1968. The effect of plant spacing on the numbers of aphids trapped over the groundnut crop. Ann. Appl. Biol. 61:289-294.

2. Allison, D., and Pike, K. S. 1988. An inexpensive suction trap and its use in an aphid monitoring network. J. Agric. Entomol. 5:103-107.

3. Antignus, Y. 2000. Manipulation of wavelength-dependent behaviour of insects: An IPM tool to impede insects and restrict epidemics of insect-borne viruses. Virus Res. 71:213-220.

4. Beemster, A. B. R., and Rozendaal, A. 1972. Potato viruses: Properties and symptoms. Page 115-143 in: Viruses of Potatoes and Seed Potato Production. J. A. de Bokx, ed. Pudoc, Wageningen, The Netherlands.

5. Biggerstaff, B. J. 2006. PooledInfRate, Version 3.0: A Microsoft ${ }^{\circledR}$ Excel $®$ Add-In to compute prevalence estimates from pooled samples. Centers for Disease Control and Prevention, Fort Collins, CO.

6. Birch, L. C. 1948. The intrinsic rate of natural increase of an insect population. J. Anim. Ecol. 17:15-26.

7. Boiteau, G. 1997. Comparative propensity for dispersal of apterous and alate morphs of three potato-colonizing aphid species. Can. J. Zool. 75:1396-1403.

8. Boiteau, G., and Osborn, W. P. L. 1997. Behavioural effects of imidacloprid, a new nicotinyl insecticide, on the potato aphid, Macrosiphum euphorbiae (Thomas) (Homoptera, Aphididae). Can. Entomol. 129:241-249.

9. Boiteau, G., and Singh, R. P. 1999. Field assessment of imidacloprid to reduce the spread of PVYO and PLRV in potato. Am. J. Potato Res. 76:31-36.

10. Broadbent, L., and Tinsley, T. W. 1951. Experiments on the colonization of potato plants by apterous and by alate aphids in relation to the spread of virus diseases. Ann. Appl. Biol. 38:411-424.

11. Butler, C. D., and O'Neil, R. J. 2006. Defensive response of the soybean aphid (Hemiptera: Aphididae) to predation by insidious flower bug (Hemiptera: Anthocoridae). Ann. Entomol. Soc. Am. 99:317-320.

12. Clark, A. J., and Perry, K. L. 2002. Transmissibility of field isolates of soybean viruses by Aphis glycines. Plant Dis. 86:1219-1222.

13. Clark, T. L., Puttler, B., and Bailey, W. C. 2006. Is horsenettle, Solanum carolinense L. (Solanaceae), an alternate host for soybean aphid, Aphis glycines Matsumura (Hemiptera: Aphididae)? J. Kans. Entomol. Soc. 79:380383.

14. Damsteegt, V., Stone, A., Schneider, W., Sherman, D., Gildow, F., and Luster, D. 2005. The soybean aphid, Aphis glycines, a new vector of endemic dwarfing and yellowing isolates of soybean dwarf luteovirus. (Abstr.) Phytopa- thology 95:S22

15. Davis, J. A., Radcliffe, E. B., and Ragsdale, D. W. 2005. Soybean aphid, Aphis glycines Matsumura, a new vector of Potato virus $Y$ in potato. Am. J. Potato Res. 81:101-105.

16. Davis, J. A., Radcliffe, E. B., Schrage, W., and Ragsdale, D. W. Vector and virus IPM for seed potato production in: Insect Pest Management: Concepts, Tactics, Strategies and Case Studies. E. B. Radcliffe, W. D. Hutchison, and R. E. Cancelado, eds. Cambridge University Press, Cambridge, UK. In press.

17. Dawson, G. W., Griffiths, D. C., Picket, J. A., Plumb, R. T., Woodcock, C. M., and ZhongNing, Z. 1988. Structure/activity studies on aphid alarm pheromone derivatives and their field use against transmission of Barley yellow dwarf virus. Pestic. Sci. 22:17-30.

18. DiFonzo, C. D., Ragsdale, D. W., Radcliffe, E. B., Gudmestad, N. C., and Secor, G. A. 1996. Crop borders reduce potato virus $\mathrm{Y}$ incidence in seed potato. Ann. Appl. Biol. 129:289-302.

19. DiFonzo, C. D., Ragsdale, D. W., Radcliffe, E. B., Gudmestad, N. C., and Secor, G. A. 1997. Seasonal abundance of aphid vectors of Potato virus $Y$ in the northern Great Plains of Minnesota and North Dakota. J. Econ. Entomol. 90:824-831.

20. Fehr, W. R., Caviness, C. E., Burmood, D. T. and Pennington, J. S. 1971. Stage of development descriptions for soybeans, Glycine max (L.) Merrill. Crop Sci. 11:929-931.

21. Flanders, K. L., Radcliffe, E. B., and Ragsdale, D. W. 1991. Potato leafroll virus spread in relation to densities of green peach aphid (Homoptera: Aphididae): Implications for management thresholds for Minnesota seed potatoes. J. Econ. Entomol. 84:1028-1036.

22. Flanders, K. L., Ragsdale, D. W., and Radcliffe, E. B. 1990. Use of enzyme-linked immunosorbent assay to detect potato leafroll virus in field grown potatoes, cv. Russet Burbank. Am. Potato J. 67:589-602.

23. George, W. L., Jr., and Kring, J. B. 1971. Virus protection of late season summer squash with aluminum mulch. Conn. AES Bull. 239.

24. Gibson R. W., Pickett J. A., Dawson, G. W., Rice, A. D., and Stribley, M. F. 1984. Effects of aphid alarm pheromone derivatives and related compounds on non- and semi-persistent plant virus transmission by Myzus persicae. Ann. Appl. Biol. 104:203-209.

25. Hille Ris Lambers, D. 1972. Aphids: Their life cycles and their role as virus vectors. Page 3756 in: Viruses of Potatoes and Seed-potato Production. J. A. de Bokx, ed. Pudoc, Wageningen, The Netherlands.

26. Hodgson, E. W., Venette, R. C., Abrahamson, M., and Ragsdale, D. W. 2005. Alate production of soybean aphid (Homoptera: Aphididae) in Minnesota. Environ. Entomol. 34:14561463.

27. ICTVdB Management. 2006. 00.039.0.02.001 Potato leafroll virus in: ICTVdB - The Universal Virus Database, version 4. C. BüchenOsmond, ed. Columbia University, New York.

28. Iwaki, M., Roechan, M., Hibino, H., Tochihara, H., and Tantera, D. M. 1980. A persistent aphidborne virus of soybean, Indonesian soybean dwarf virus. Plant Dis. 64:1027-1030.

29. Kennedy, J. S., Day, M. F. and Eastop, V. F 1962. A Conspectus of Aphids as Vectors of Plant Viruses. Commonwealth Institute of Entomology, London.

30. Killick, R. J. 1979. The effect of infection with potato leafroll virus (PLRV) on yield and some of its components in a variety of potato ( $\mathrm{So}$ lanum tuberosum). Ann. Appl. Biol. 91:67-74.

31. Kring, J. B. 1970. Determining the number of aphids over reflective surfaces. J. Econ. Entomol. 63:1350-1353.

32. Landis, D., Brewer, M., and Heimpel, G. 2003. Soybean aphid and parasitoids 2003: A survey of NCR-125 cooperating states. http://www. 
ncera125.ent.msu.edu/StateRpts2003MI.htm

33. Marco, S. 1993. Incidence of nonpersistently transmitted viruses in pepper sprayed with whitewash, oil, and insecticide, alone or combined. Plant Dis. 77:1119-1122.

34. McCornack, B., Ragsdale, D. W., and Venette, R. C. 2004. Demography of soybean aphid (Homoptera: Aphididae) at summer temperatures. J. Econ. Entomol. 97:854-861.

35. Mueller, E. E., and Grau, C. R. 2007. Seasonal progression, symptom development, and yield effects of Alfalfa mosaic virus epidemics on soybean in Wisconsin. Plant Dis. 91:266-272.

36. Myers, S. W., Hogg, D. B., and Wedberg, J. L. 2005. Determining the optimal timing of foliar insecticide applications for control of soybean aphid (Hemiptera: Aphididae) on soybean. J. Econ. Entomol. 98:2006-2012.

37. Nault, B. A., Shah, D. A., Dillard, H. R., and McFaul, A. C. 2004. Seasonal and spatial dynamics of alate aphid dispersal in snap bean fields in proximity to alfalfa and implications for virus management. Environ. Entomol. 33:1593-1601.

38. Nault, L. R., and Phelan, P. L. 1984. Alarm pheromones and sociality in pre-social insects. Page 237-258 in: Chemical Ecology of Insects. W. S. Bell and R. T. Cardé, eds. Chapman and Hall, New York.

39. Ostlie, K. 2001. Soybean aphid reduces yields: Harvest results from insecticide strip trials. University of Minnesota, St. Paul, MN. Online at: http://www.soybeans.umn.edu/crop/insects/ aphid/studyresults.htm.

40. Phelan, P., Montgomery, M. E., and Nault, L. R. 1976. Orientation and locomotion of apterous aphids dislodged from their hosts by alarm pheromone. Ann. Entomol. Soc. Am. 69:11531156.

41. Radcliffe, E. B., and Ragsdale, D. W. 2002. Aphid-transmitted potato viruses: The importance of understanding vector biology. Am. J. Potato Res. 79:353-386.

42. Radcliffe, E. B., Ragsdale, D. W., Suranyi, R. A., Difonzo, C. D., and Hladilek, E. E. 2008. Aphid Alert: How it came to be, what it achieved, and why it proved unsustainable. Pages 244-260 in: Areawide Pest Management Theory and Implementation. O. Koul, G. Cu- perus, and N. Elliot, eds. CABI International, Wallingford, UK.

43. Ragsdale, D. W., McCornack, B. P., Venette, R. C., Potter, B. D., Macrae, I. V., Hodgson, E. W., O’Neal, M. E., Johnson, K. D., O’Neil, R. J., Difonzo, C. D., Hunt, T. E., Glogoza, P. A., and Cullen, E. M. 2007. Economic threshold for soybean aphid (Hemiptera: Aphididae). J. Econ. Entomol. 100:1258-1267.

44. Ragsdale, D. W., Radcliffe, E. B., and DiFonzo, C. D. 2001. Epidemiology and field control of PVY and PLRV. Page 237-270 in: Virus and Virus-like Diseases of Potatoes and Production of Seed-Potatoes. G. Loebenstein, P. H. Berger, A. A. Brunt, and R. H. Lawson, eds. Kluwer Academic Publisher, Dordrecht, The Netherlands.

45. Ruppel, R. F. 1983. Cumulative insect-days as an index of crop protection. J. Econ. Entomol. 76:375-377.

46. Setiawan, D. G., and Ragsdale, D. W. 1987. Use of aluminum-foil and oat-straw mulches for controlling aster leafhopper, Macrosteles fascifrons (Homoptera: Cicadellidae), and aster yellows in carrots. Gt. Lakes Entomol. 20:103-109.

47. Singh, M. N., Khurana, S. M. P., Nagaich, B. B., and Agrawal, H. O. 1982. Efficiency of Aphis gossypii and Acyrthosiphon pisum in transmitting potato viruses $\mathrm{Y}$ and leafroll. Page 289-293 in: Potatoes in Developing Countries. B. B. Nagaich et al., eds. Indian Potato Association and Central Potato Research Institute, Simla.

48. Singh, R. P., Kurz, J., Boiteau, G., and Bernard, G. 1995. Detection of potato leafroll virus in single aphids by the reverse transcription polymerase chain reaction and its potential epidemiological application. J. Virol. Methods 55:133-143.

49. Smith, J. G. 1969. Some effects of crop background on populations of aphids and their natural enemies on Brussels sprouts. Ann. Appl. Biol. 63:326-329.

50. Snedecor, G. W., and Cochran, W. G. 1989. The binomial distribution. Pages 107-134 in: Statistical Methods, 8th ed. Iowa State University, Ames.

51. Sutula, C. L., Gillett, J. M., Morrissey, S. M., and Ramsdell, D. C. 1986. Interpreting ELISA data and establishing the positive-negative threshold. Plant Dis. 70:722-726.

52. Sylvester, E. S. 1980. Circulative and propagative virus transmission by aphids. Annu. Rev. Entomol. 25:257-286.

53. Tjallingii, W. F., and Hogen Esch, T. H. 1993 Fine structure of aphid stylet routes in plant tissues in correlation with EPG signals. Physiol. Entomol. 18:317-328.

54. van den Heuvel, J. F. J. M., de Blank, C. M., Peters, D., and van Lent, J. W. M. 1995. Localization of potato leafroll virus in leaves of secondarily-infected potato plants. Eur. J. Plant Pathol. 101:567-571.

55. Venette, R. C., Moon, R. D., and Hutchison, W. D. 2002. Strategies and statistics of sampling for rare individuals. Annu. Rev. Entomol. 47:143-174.

56. Venette, R. C., and Ragsdale, D. W. 2004 Assessing the invasion by soybean aphid (Hemiptera: Aphididae): Where will it end? Ann. Entomol. Soc. Am. 97:219-226.

57. Wang, R. Y., and Ghabrial, S. A. 2002. Effect of aphid behavior on efficiency of transmission of Soybean mosaic virus by the soybeancolonizing aphid, Aphis glycines. Plant Dis. 86:1260-1264.

58. Wang, R. Y., Kritzman, A., Hershman, D. E., and Ghabrial, S. A. 2006. Aphis glycines as vector of persistently and nonpersistently transmitted viruses and potential risks for soybean and other crops. Plant Dis. 90:920-926.

59. Whitworth, J. L., Mosley, A. R., and Reed, G. L. 2000. Monitoring current season potato leafroll virus movement with an immunosorbent direct tissue blotting assay. Am. J. Potato Res. 77:1-9.

60. Woodford, J. A. T. 1988. The impact of cropping policy on methods to control potato leafroll virus. Aspects Appl. Biol. 17:163-171.

61. Wyman, J. A., Toscano, N. C., Kido, K., Johnson, H., and Mayberry, K. S. 1979. Effect of mulching on the spread of aphid-transmitted watermelon mosaic virus to summer squash. J. Econ. Entomol. 72:139-153.

62. Yang, S. L., and Zettler, F. W. 1975. Effects of alarm pheromones on aphid probing behavior and virus transmission efficiency. Plant Dis. Rep. 59:902-905. 